\title{
PENGARUH PEMBERIAN PUPUK KOMPOS DAN PUPUK NPK PHONSKA TERHADAP PERTUMBUHAN DAN HASIL TANAMAN MENTIMUN (Cucumis sativus L) VARIETAS HARMONY
}

\author{
Wendelinus Sai Mali ${ }^{1}$, Marisi Napitupulu ${ }^{2}$, Zuhdi Yahya ${ }^{2}$ \\ ${ }^{1}$ Agroteknologi, Fakultas Pertanian, Universitas 17 Agustus 1945 Samarinda 75124, \\ Indonesia. J1. Ir. H. Juanda No.80 Samarinda, 75124. \\ ${ }^{2}$ Dosen Fakultas Pertanian, Universitas 17 Agustus 1945 Samarinda 75124, Indonesia. J1. \\ Ir. H. Juanda No.80 Samarinda, 75124. \\ E-Mail: wendelin1978@gmail.com
}

\begin{abstract}
ABSTRAK
Pengaruh Pupuk Kompos dan Pupuk NPK Phonska Terhadap Pertumbuhan dan Hasil Tanaman Mentimun (Cucumissativus L.) Varietas Harmony. Prospek pengembangan budidaya mentimun secara komersial yang dikelola secara agribisnis semakin cerah, karena pemasaran hasilnya tidak hanya dilakukan di dalam negeri (domestik), tetapi juga ke luar negeri (ekspor). Tujuan penelitian untuk mengetahui pengaruh pupuk kompos dan pupuk NPK Phonska serta interaksinya terhadap pertumbuhan dan hasil tanaman mentimun, danuntuk memperoleh dosis pupuk kompos dan pupuk NPK Phonska yang optimum untuk menghasilkan produksi yang maksimal.

Penelitian menggunakan analisis faktorial 3x4 dalam Rancangan Acak Lengkap (RAL), dengan 3 kali ulangan. Faktor penelitian terdiri atas 2 faktor. Faktor I adalah Pupuk Kompos (K), terdiri atas 3 taraf, yaitu :tanpa pupuk kompos atau kontrol $\left(\mathrm{k}_{0}\right)$, dosis pupuk kompos 10 ton/ha setara $400 \mathrm{~g} /$ tanaman $\left(\mathrm{k}_{1}\right)$, dan dosis pupuk kompos 20 ton/ha setara $800 \mathrm{~g} /$ tanaman $\left(\mathrm{k}_{2}\right)$. Faktor II adalah Pupuk NPK Phonska (P), terdiri atas 4 taraf, yaitu : tanpa pupuk NPK Phonska atau kontrol $\left(\mathrm{p}_{0}\right)$, dosis pupuk NPK Phonska $100 \mathrm{~kg} / \mathrm{ha}$ setara 4 $\mathrm{g} /$ tanaman $\left(\mathrm{p}_{1}\right)$, dosis pupuk NPK Phonska $200 \mathrm{~kg} / \mathrm{ha}$ setara $8 \mathrm{~g} / \operatorname{tanaman}\left(\mathrm{p}_{2}\right)$, dan dosis pupuk NPK Phonska $300 \mathrm{~kg} / \mathrm{ha}$ setara $12 \mathrm{~g} / \mathrm{tanaman}$.

Hasil penelitian menunjukkan bahwa perlakuan pupuk kompos tidak berpengaruh nyata terhadap panjang tanaman umur 20 hari setelah tanam dan umur berbunga. Berpengaruh nyata terhadap jumlah buah per tanaman. Berpengaruh sangat nyata terhadap panjang tanaman umur 40 hari setelah tanam, panjang buah, diameter buah dan produksi buah per tanaman.

Perlakuan pupuk NPK Phonska tidak berpengaruh nyata terhadap panjang tanaman umur 20 hari dan umur 40 hari setelah tanam dan umur berbunga. Berpengaruh sangat nyata terhadap panjang buah, diameter buah, jumlah buah per tanaman dan produksi buah per tanaman.

Interaksi perlakuan antara pupuk kompos dan pupuk NPK Phonska tidak berpengaruh nyata terhadap panjang tanaman umur 20 hari dan umur 40 hari setelah tanam, umur berbunga, diameter buah dan jumlah buah/tanaman. Berpengaruh sangat nyata terhadap produksi buah/tanaman. Berat buah tertinggi terdapat pada perlakuan $\mathrm{k}_{2} \mathrm{p}_{3}$ (dosis pupuk kompos 20 ton/ha dan dosis pupuk NPK Phonska $300 \mathrm{~kg} / \mathrm{ha}$ ), yaitu 3,94 $\mathrm{kg} /$ tanaman, sedangkan berat buah terendah terdapat pada perlakuan $\mathrm{k}_{0} \mathrm{p}_{0}$ (tanpa pupuk kompos dan pupuk NPK Phonska atau kontrol), yaitu $2,54 \mathrm{~kg} /$ tanaman.
\end{abstract}

Kata kunci : Mentimun, Pertumbuhan, Pupuk Kompos, Pupuk NPK Phonska.

\begin{abstract}
Effect of Compost Fertilizer and NPK Phonska Fertili the Growth and Produciton of Cucumber Crop (Cucumis sativus L.) Harmony Variety. The prospect of developing commercially managed cucumber cultivation in agribusiness is increasingly bright, because the marketing of the results is not only done domestically (domestically), but also abroad (exports). The purpose of this research was to know the effect of compost and NPK Phonska fertilizer and its interaction on the growth and yield of cucumber, and also to get the optimum dosage of compost and NPK Phonska fertilizer to produce maximum production.

The study used $3 x 4$ factorial analysis in Completely Randomized Design (RAL), with 3 replications. The
\end{abstract}


research factor consists of 2 factors. Factor I was Compost Fertilizer (K), consisting of 3 levels, namely: no compost application or control ( $\left.k_{0}\right), 10$ tons/ha equaled to $400 \mathrm{~g} / \mathrm{crop}\left(k_{1}\right)$, and 20 tons/ha equaled to800 g/crop $\left(k_{2}\right)$. The second factor was NPK Phonska fertilizer $(P)$ consisting of 3 levels, namely: no NPK Phonska application or control ( $\left.p_{0}\right), 100 \mathrm{~kg} / \mathrm{ha}$ equaled to $4 \mathrm{~g} / \mathrm{crop}\left(p_{1}\right), 200 \mathrm{~kg} / \mathrm{ha}$ equaled to $8 \mathrm{~g} / \mathrm{crop}\left(p_{2}\right)$, and $300 \mathrm{~kg} / \mathrm{ha}$ equaled to $12 \mathrm{~g} / \mathrm{crop}$.

The results showed that the compost fertilizer treatment do not significantly affect on the plant length at 20 days after planting and age of crop flowered. It had significant effect on the number of fruits per crop. It had very significant effect on the plant length at 40 days after planting, fruit length, fruit diameter and fruit production per crop, and fruit production/crop.

The treatment of NPK Phonska fertilizer had no significant effect on the plant length at ages 20 days and 40 days after planting and age of crop flowered. But it had very significant effect on the fruit length, fruit diameter, number of fruits per crop and fruit production per crop.

The interaction treatment between compost fertilizer and NPK Phonska fertilizer did not have significant effect on the plant length at ages 20 days and age 40 days after planting, age of crop flowered, fruit diameter and number of fruit/crop. But it had very significant effect on the fruit production/crop. The highest fruit weight was found in the $k_{2} p_{3}$ treatment, ie $3.94 \mathrm{~kg} / \mathrm{crop}$, while the lowest one was found in the $k_{0} p_{0}$ treatment, ie $2.54 \mathrm{~kg} / \mathrm{crop}$.

Key words : Compost Fertilizer, Cucumber, Growth, Phonska NPK Fertilizer.

\section{PENDAHULUAN}

Mentimun atau Timun (Cucumis sativus L) merupakan salah satu jenis sayuran dari keluarga labu-labuan (Cucurbitaceae) yang sudah sangat popular dan sangat digemari oleh hampir seluruh masyarakat khususnya Indonesia. Meskipun demikian usahatani mentimun masih dianggap usaha sampingan dan produksinya secara nasional masih sangat rendah, yakni antara 3,4-4,8 ton/ha. Oleh sebab itu peningkatan produksi tanaman mentimun sangat penting artinya bagi pemenuhan kebutuhan pasar. Seiring dengan bertambahnya jumlah penduduk Indonesia akan berpengaruh terhadap naiknya ketersediaan konsumsi sayuran. Di Indonesia anjuran konsumsi sayuran untuk mencapai sehat gizi adalah 65,5 $\mathrm{kg} / \mathrm{kapita} / \mathrm{tahun}$, sedangkan konsumsi saat ini baru mencapai $80 \%$, salah satunya adalah dengan meningkatkan produksi mentimun (Rukmana, 2010).

Penelitian dan pengembangan tanaman hortikultura, mentimun termasuk skala prioritas rendah. Ini berarti bahwa mentimun termasuk komoditas potensial, tetapi belum berkembang sebagai komoditas utama. Meskipun demikian, berdasarkan kenyataan di lapangan akhirakhir ini pengembangan budidaya mentimun menempati urutan ke empat (4) setelah cabai, kacang panjang dan bawang merah, dari 18 jenis sayuran komersial yang dihasilkan di Indonesia. Prospek pengembangan budidaya mentimun secara komersial yang dikelola secara agribisnis semakin cerah, karena pemasaran hasilnya tidak hanya dilakukan di dalam negeri (domestik), tetapi juga ke luar negeri (ekspor). Di daerah Sangatta mentimun masih di datangkan dari daerah lain seperti dari Jawa, Sulawesi sehingga kebutuhan lokal harus didatangkan dari luar daerah. Pasar yang potensial untuk ekspor adalah : Malaysia, Singapura, Taiwan, Hongkong, Pakistan, Prancis, Uni Emirat Arab, Inggris, Belanda, Thailand, Saudi Arabia, Jepang, Siprus dan Brunai Darussalam (Sumpena, 2008).

Adanya peluang pasar yang baik untuk produksi tanaman mentimun, baik di dalam negeri maupun di luar negeri, merupakan kesempatan yang sangat baik bagi petani mentimun dan sekaligus merupakan tantangan, karena kenyataannya bahwa produksi mentimun masih sangat rendah. Masalah lingkungan pertanaman atau iklim mikro di sekitar tanaman sangat berpengaruh terhadap pertumbuhan tanaman karena 
berhubungan dengan iklim mikro seperti suhu udara, kelembaban udara dan tanah. Tentu diperlukan upaya untuk meningkatkan produksi per satuan luas, yaitu dengan perbaikan teknologi budidaya, terutama dengan menggunakan pupuk organik.seperti kompos yang bahannya ada disekitar lingkungan atau kebun yang lebih ramah lingkungan dan juga penggunaan pupuk NPK Phonska.

Penggunaan pukuk kompos pada budidaya tanaman mentimun akan memperbaiki kehidupan jasad renik tanah secara biologis, mempertahankan kelembaban tanah, sehingga mengurangi stres tanaman pada saat musim kemarau, dan juga meningkatkan kesuburan tanah secara kimiawi. Pupuk kompos ini juga mudah didapatkan dan pengolahannya juga tidak begitu sulit karena bahanbahannya terbuat dari kotoran hewan, dari tumbuhan yang mengalami proses pembusukan dengan adanya mikroorganisme pengurai. Penggunaan pupuk kompos ini pada tanaman mentimun adalah 10-20 ton/ha (Rukmana, 2010). Penggunaan pupuk anorganik seperti pupuk NPK Phonska juga dianjurkan untuk budidaya tanaman mentimun asalkan sesuai dengan dosis anjuran karena selain memiliki banyak kelebihan juga banyak kelemahannya dibandingkan dengan menggunakan pupuk organik (Lingga dan Marsono, 2009).

Tujuan penelitian adalah untuk mengetahui pengaruh pemberian pupuk kompos dan pupuk majemuk NPK Phonska serta interaksinya terhadap pertumbuhan dan hasil tanaman mentimun (Cucumis sativus $\mathrm{L}$ ) varietas Harmony. Untuk mengetahui dosis pupuk kompos dan pupuk NPK Phonska yang tepat terhadap pertumbuhan dan produksi tanaman mentimun varietas (Cucumis sativus L) Harmony.

\section{METODA PENELITIAN}

\subsection{Tempat dan Waktu}

Penelitian dilaksanakan di Jl. Pendidikan Sangatta Utara, Kecamatan Sangatta Utara, Kabupaten Kutai Timur, Provinsi Kalimantan Timur. Pada bulan Februari-Mei 2017.

\subsection{Bahan dan Alat}

Bahan yang digunakan dalam penelitian ini adalah sebagai berikut : pupuk NPK Phonska, pupuk kompos, benih mentimun varietas Harmony, Basudin 60 EC, Malathion 40 WP (0,1-0,2\%), Furadan 3 G.

Alat yang digunakan, yaitu : arit, parang, cangkul, garu, gembor, polibag, meteran, alat tulis-menulis, camera, tali rapia, turus, timbangan analitik.

\subsection{Rancangan Percobaan}

Rancangan yang digunakan dalam penelitian ini adalah Rancangan Acak Lengkap (RAL) dengan analisis faktorial 3 x 4, dan ulangan sebanyak 4 kali, sehingga diperoleh 48 kombinasi perlakuan dan ulangan. Faktor perlakuan terdiri atas dua (2) faktor, yaitu :

Faktor pertama (I) adalah pupuk Kompos (K), yang terdiri atas 3 taraf, yaitu :

$\mathrm{k}_{0}: \quad$ tanpa pupuk kompos (kontrol)

$\mathrm{k}_{1}$ : dosis pupuk kompos 10 ton/ha setara $400 \mathrm{~g} /$ tanaman

$\mathrm{k}_{2}$ : dosis pupuk kompos 20 ton/ha setara $800 \mathrm{~g} /$ tanaman Faktor kedua (2) adalah Pupuk NPK Phonska (P), yang terdiri atas 4 taraf, yaitu :

$\mathrm{p}_{0}: \quad$ tanpa pupuk majemuk Phonska (kontrol)

$\mathrm{p}_{1}: \quad 100 \mathrm{~kg} / \mathrm{ha}$ pupuk NPK Phonska (4 g/tanaman)

$\mathrm{p}_{2}: \quad 200 \mathrm{~kg} / \mathrm{ha}$ pupuk NPK Phonska (8 g/tanaman) 
$p_{3}: \quad 300 \mathrm{~kg} / \mathrm{ha}$ pupuk NPK Phonska (12 g/tanaman)

Adapun kombinasi perlakuan pada penelitian ini, adalah :

$\begin{array}{llll}\mathrm{k}_{0} \mathrm{p}_{0} & \mathrm{k}_{0} \mathrm{p}_{1} & \mathrm{k}_{0} \mathrm{p}_{2} & \mathrm{k}_{0} \mathrm{p}_{3}\end{array}$

$\begin{array}{llll}\mathrm{k}_{1} \mathrm{p}_{0} & \mathrm{k}_{1} \mathrm{p}_{1} & \mathrm{k}_{1} \mathrm{p}_{2} & \mathrm{k}_{1} \mathrm{p}_{3}\end{array}$

$\begin{array}{llll}\mathrm{k}_{2} \mathrm{p}_{0} & \mathrm{k}_{2} \mathrm{p}_{1} & \mathrm{k}_{2} \mathrm{p}_{2} & \mathrm{k}_{2} \mathrm{p} 3\end{array}$

\subsection{Prosedur Penelitian}

Persiapan media tanam.

Tanah sebagai media tanam adalah tanah top soil yang berasal dari sekitar tempat penelitian, kemudian dibersihkan dari akar, kayu atau batu, kemudian ditaruh diatas terpal dan dikeringanginkan. Pada media tanam diberikan Furadan 3 G sebanyak 3 gram per polibag saat pengolahan tanah, kemudian tanah dimasukkan ke dalam polibag sebanyak $15 \mathrm{~kg}$ (ukuran polibag $40 \mathrm{~cm}$ x $50 \mathrm{~cm}$ ), yaitu sebanyak 48 polibag, untuk penyulaman tanaman disediakan 12 polibag. Kemudian disusun sesuai hasil pengacakan dengan cara undian seperti terlihat pada Lampiran Gambar 1. Jarak antara polibag $1 \mathrm{~m}$.

\section{Pemberian pupuk kompos}

Pupuk kompos diberikan satu kali sesuai dosis perlakuan, yaitu : tanpa pupuk kompos $\left(\mathrm{k}_{0}\right)$, dan dosis pupuk kompos 10 ton/ha setara 400 g/tanaman $\left(\mathrm{k}_{1}\right)$, dan dosis pupuk kompos 20 ton/ha setara 800 g/tanaman $\left(\mathrm{k}_{2}\right)$, dengan cara mencampurkan ke dalam tanah secara merata dan dibenamkan ke dalam tanah, diberikan 2 minggu sebelum tanam.

Penanaman
Benih diseleksi dengan cara merendam dalam air selama satu jam, lalu yang mengapung dibuang dan yang tenggelam dijadikan bibit. Benih mentimun di tanam langsung dalam polibag dengan cara di tugal. Setiap lobang tanam di isi dua (2) benih. Setelah tanaman tumbuh dan telah berumur 1 minggu, maka dilakukan penjarangan dan setiap lobang tanam ditinggal satu (1) tanaman yang baik.

\section{Pemberian pupuk NPK Phonska}

Pemberian pupuk majemuk Phonska disesuaikan dengan dosis perlakuan, dan diberikan pada saat tanam dengan dosis masing-masing sebagai berikut : tanpa pupuk atau kontrol $\left(\mathrm{p}_{0}\right), 100$ $\mathrm{kg} / \mathrm{ha}$ atau $4 \mathrm{~g} /$ tamnaman $\left(\mathrm{p}_{1}\right), 200$ $\mathrm{kg} / \mathrm{ha}$ atau $8 \mathrm{~g} /$ petak $\left(\mathrm{p}_{2}\right)$, dan 300 $\mathrm{kg} / \mathrm{ha}$ atau $12 \mathrm{~g} /$ petak $\left(\mathrm{p}_{3}\right)$. Pemberian pupuk dilakukan bersamaan dengan waktu tanam, dengan cara disebarkan disekitar tanaman dan dicampur dengan tanah supaya rata.

Pemasangan ajir

Bahan turus yang dipakai berasal dari kayu khusus untuk turus dari petani, dengan panjang $2 \mathrm{~m}$, dan di pasang di sisi tiap-tiap tanaman, dilakukan pada umur 2 minggu setelah tanam.

Pemeliharaan tanaman

\section{a. Penyiraman}

Penyiraman dilakukan 2 kali sehari, yaitu pagi dan sore, dan bila keadaan tanah masih basah (bekas hujan), maka penyiraman disesuaikan dengan keadaan kelembaban tanahnya. 
Penyulaman dilakukan bila ada tanaman yang tidak tumbuh atau mati satu minggu setelah tanam.

c. Penyiangan

Penyiangan dilakukan sesering mungkin untuk menghindari persaingan dengan gulma, dengan cara mencabut atau menggunakan alat arit/lingga.

\section{d. Penyiraman}

Penyiraman dilakukan 2 kali sehari, yaitu pagi dan sore, dan bila keadaan tanah masih basah (bekas hujan), maka penyiraman disesuaikan dengan keadaan kelembaban tanahnya.

Pemanenan

\section{a. Waktu Panen}

Tanaman mulai bisa di panen pada umur 40 hari setelah tanam, dengan ciri-ciri kulit buah sudah mulus/bersih dan pada kulit buah sedikit berwarna kuning.

\section{b. Cara Panen}

Cara pemanenan pada tanaman mentimun adalah dengan cara memetik buah yang telah masak muda dan segar dengan interval panen 3 hari sekali, dan dilakukan sebanyak 4 kali penen.

\subsection{Pengamatan dan Pengambilan Data}

Pengambilan data dilakukan dengan cara mengukur/mengamati parameter berikut :

Panjang Tanaman $(\mathrm{cm})$

Panjang tanaman mentimun diukur dengan cara meletakkan meteran dari pangkal batang sampai ujung tanaman, diikuti sesuai dengan lekuk tanaman. Pengukuran dilakukan pada umur 20 dan 40 hari setelah tanam.

\begin{abstract}
Umur Berbunga (hari)
Umur tanaman saat berbunga di hitung dengan cara melihat munculnya bunga pertama kali.
\end{abstract}

Panjang Buah (cm)

Panjang buah mentimun diukur dengan cara meletakkan meteran, mulai dari pangkal buah sampai ujung buah.

Diameter Buah $(\mathrm{cm})$

Diameter buah mentimun di ukur dengan cara mengukur bagian tengah dari buah mentimun pada setiap kali panen dengan meteran lalu dibagi $\pi(3,14)$

Jumlah Buah Per Tanaman (buah)

Jumlah buah per tanaman dihitung dengan cara menjumlahkan buah yang telah dipanen pada tiap kali panen, yaitu sebanyak 4 kali panen.

Berat Buah Per Tanaman (kg)

Produksi buah per tanaman diperoleh dengan cara menimbang buah yang telah dipanen pada setiap kali panen, yaitu sebanyak 4 kali panen.

\subsection{Analisis Data}

Untuk mengetahui pengaruh perlakuan pupuk kandang kompos dan pupuk NPK Phonska serta interaksinya pada pertumbuhan dan hasil tanaman mentimun variatas Harmony, maka digunakan Sidik Ragam (Yitnosumarto, 1993).

Bila hasil sidik ragam pada perlakuan tidak berpengaruh nyata dimana FHitung < F-Tabel 5\%, maka tidak dilakukan uji lanjutan, tetapi bila hasil sidik ragam berpengaruh nyata dimana F-Hitung $\geq$ F-Tabel 5\%, atau berpengaruh sangat nyata dimana FHitung $\geq$ F-Tabel 1\%, maka dilakukan uji lanjutan untuk 
membandingkan dua rata-rata taraf perlakuan dengan menggunakan uji Beda Nyata Terkecil (BNT) pada taraf $5 \%$.
Rumus Umum Uji BNT disajikan sebagai berikut :

$$
\text { BNT } 5 \%=\mathrm{t}-\text { Tabel }(\alpha, \mathrm{db}) \quad \mathrm{x} \sqrt{\frac{2 \text { KT Galat }}{\text { r.t }}}
$$

Keterangan :

t-Tabe $\quad$ Nilai Tabel ( sebaran nilai pada t-student $\alpha 5 \%$ dengan $\mathrm{db}$ nya)

KT Galat $\quad=\quad$ Kuadrat Tengah Galat

$\mathrm{r} \quad$ Ulangan

\section{HASIL PENELITIAN DAN PEMBAHASAN}

\subsection{Panjang Tanaman Umur 20 Hari Setelah Tanam}

Hasil sidik ragam menunjukkan bahwa perlakuan pupuk kompos (K) dan pupuk NPK Phonska (P) serta Interaksinya $(\mathrm{KxP})$ tidak berpengaruh nyata terhadap panjang tanaman umur 20 hari setelah tanam (Tabel 1).

Tabel 1. Rekapitulasi Data Penelitian Pengaruh Pupuk Kompos dan NPK Phonska Terhadap Pertumbuhan dan Hasil Tanaman Mentimun (Cucumis sativus L.) Varietas Harmony

\begin{tabular}{|c|c|c|c|c|c|c|c|}
\hline \multirow{2}{*}{$\begin{array}{c}\text { Faktor } \\
\text { Perlakuan }\end{array}$} & \multicolumn{2}{|c|}{$\begin{array}{l}\text { Panjang Tanaman } \\
(\mathrm{cm})\end{array}$} & \multirow{2}{*}{$\begin{array}{l}\text { Umur } \\
\text { Berbunga } \\
\text { (hari) }\end{array}$} & \multirow{2}{*}{$\begin{array}{c}\text { Panjang } \\
\text { Buah }(\mathrm{cm})\end{array}$} & \multirow{2}{*}{$\begin{array}{l}\text { Diameter } \\
\text { Buah }(\mathrm{cm})\end{array}$} & \multirow{2}{*}{$\begin{array}{c}\text { Jumlah } \\
\text { Buah/ } \\
\text { Tanaman } \\
\text { (buah) }\end{array}$} & \multirow{2}{*}{$\begin{array}{c}\text { Berat } \\
\text { Buah/ } \\
\text { Tanama } \\
\text { n (kg) }\end{array}$} \\
\hline & $20 \mathrm{HST}$ & 40 HST & & & & & \\
\hline $\begin{array}{l}\text { Pupuk } \\
\text { Kompos (K) } \\
\text { Sidik Ragam }\end{array}$ & tn & $* *$ & tn & $* *$ & $* *$ & $*$ & $* *$ \\
\hline 0 ton/ha $\left(\mathrm{k}_{0}\right)$ & 20,25 & $111,31 \mathrm{~b}$ & 21,41 & $23,59 \mathrm{c}$ & $5,49 b$ & $9,25 \mathrm{~b}$ & $2,61 \mathrm{c}$ \\
\hline 10 ton/ha $\left(\mathrm{k}_{1}\right)$ & 23,83 & $116,88 \mathrm{~b}$ & 20,91 & $24,13 \mathrm{~b}$ & $5,67 \mathrm{a}$ & $9,50 \mathrm{ab}$ & $2,78 \mathrm{~b}$ \\
\hline 20 ton/ha $\left(\mathrm{k}_{2}\right)$ & 24,88 & $142,69 \mathrm{a}$ & 20,30 & $24,63 \mathrm{a}$ & $5,73 \mathrm{a}$ & $9,75 \mathrm{a}$ & $3,45 \mathrm{a}$ \\
\hline $\begin{array}{l}\text { Pupuk NPK } \\
\text { Phonska (P) } \\
\text { Sidik Ragam }\end{array}$ & tn & tn & tn & $* *$ & $* *$ & $* *$ & $* *$ \\
\hline $0 \mathrm{~kg} / \mathrm{ha}\left(\mathrm{p}_{0}\right)$ & 21,67 & 116,83 & 20,71 & $22,93 \mathrm{~d}$ & $5,33 \mathrm{c}$ & $8,42 \mathrm{~d}$ & $2,79 \mathrm{~d}$ \\
\hline $100 \mathrm{~kg} / \mathrm{ha}\left(\mathrm{p}_{1}\right)$ & 23,75 & 123,25 & 20,88 & $23,78 \mathrm{c}$ & $5,48 \mathrm{c}$ & $9,00 \mathrm{c}$ & $2,88 \mathrm{c}$ \\
\hline $200 \mathrm{~kg} / \mathrm{ha}\left(\mathrm{p}_{2}\right)$ & 23,83 & 126,67 & 20,92 & $24,33 \mathrm{~b}$ & $5,74 b$ & $9,83 \mathrm{~b}$ & $2,95 \mathrm{~b}$ \\
\hline $300 \mathrm{~kg} / \mathrm{ha}\left(\mathrm{p}_{3}\right)$ & 26,33 & 127,75 & 20,97 & $25,42 \mathrm{a}$ & $5,97 \mathrm{a}$ & $10,75 \mathrm{a}$ & $3,16 \mathrm{a}$ \\
\hline $\begin{array}{l}\text { Interaksi } \\
(\mathrm{KxP}) \\
\text { Sidik Ragam }\end{array}$ & tn & tn & tn & $* *$ & tn & tn & $* *$ \\
\hline $\mathrm{k}_{0} \mathrm{p}_{0}$ & 19,25 & 98,75 & 21,13 & $22,80 \mathrm{~g}$ & 5,18 & 8,50 & $2,54 \mathrm{i}$ \\
\hline $\mathrm{k}_{0} \mathrm{p}_{1}$ & 21,25 & 117,25 & 21,59 & 23,58 ef & 5,30 & 8,75 & $2,58 \mathrm{hi}$ \\
\hline $\mathrm{k}_{0} \mathrm{p}_{2}$ & 16,50 & 100,00 & 21,35 & $23,84 \mathrm{de}$ & 5,59 & 9,50 & 2,64 hi \\
\hline $\mathrm{k}_{0} \mathrm{p}_{3}$ & 24,00 & 129,25 & 21,57 & 24,13 cde & 5,91 & 10,25 & $2,68 \mathrm{hg}$ \\
\hline $\mathrm{k}_{1} \mathrm{p}_{0}$ & 27,75 & 122,25 & 20,87 & $23,00 \mathrm{fg}$ & 5,40 & 8,50 & $2,68 \mathrm{gh}$ \\
\hline $\mathrm{k}_{1} \mathrm{p}_{1}$ & 16,75 & 101,25 & 20,98 & $23,75 \mathrm{de}$ & 5,64 & 9,00 & $2,76 \mathrm{fg}$ \\
\hline $\mathrm{k}_{1} \mathrm{p}_{2}$ & 29,25 & 121,25 & 20,87 & $24,40 \mathrm{~cd}$ & 5,81 & 10,00 & 2,80 ef \\
\hline $\mathrm{k}_{1} \mathrm{p}_{3}$ & 32,50 & 122,75 & 20,90 & $25,38 \mathrm{~b}$ & 6,81 & 10,50 & $2,87 \mathrm{e}$ \\
\hline $\mathrm{k}_{2} \mathrm{p}_{0}$ & 18,00 & 129,50 & 20,12 & $23,00 \mathrm{fg}$ & 5,40 & 8,25 & $3,16 \mathrm{~d}$ \\
\hline $\mathrm{k}_{2} \mathrm{p}_{1}$ & 33,25 & 151,25 & 20,06 & $24,00 \mathrm{de}$ & 5,49 & 9,25 & $3,29 \mathrm{c}$ \\
\hline $\mathrm{k}_{2} \mathrm{p}_{2}$ & 25,75 & 158,75 & 20,55 & $24,75 \mathrm{bc}$ & 5,82 & 10,00 & $3,41 \mathrm{~b}$ \\
\hline $\mathrm{k}_{2} \mathrm{p}_{3}$ & 22,25 & 131,25 & 20,45 & $26,75 \mathrm{a}$ & 6,19 & 11,50 & $3,94 \mathrm{a}$ \\
\hline
\end{tabular}




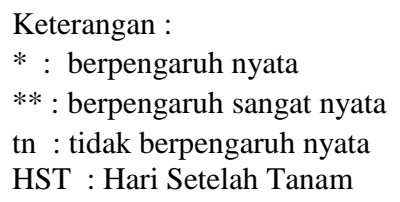

$\mathrm{k}_{0}$ : tanpa pupuk kompos (kontrol)

$\mathrm{k}_{1}$ : dosis pupuk kompos 10 ton/ha setara $400 \mathrm{~g} /$ tanaman

$\mathrm{k}_{1}$ : dosis pupuk kompos 20 ton/ha setara $800 \mathrm{~g} / \mathrm{tanaman}$

$\mathrm{p}_{0}:$ tanpa pupuk NPK Phonska (kontrol)

$\mathrm{p}_{1}$ : dosis pupuk NPK Phonska $100 \mathrm{~kg} / \mathrm{ha}$ setara $4 \mathrm{~g} /$ tanaman

$\mathrm{p}_{1}$ : dosis pupuk NPK Phonska $200 \mathrm{~kg} /$ ha setara $8 \mathrm{~g} /$ tanaman

$\mathrm{p}_{3}$ : dosis pupuk NPK Phonska $300 \mathrm{~kg} / \mathrm{ha}$ setara $12 \mathrm{~g} / \mathrm{tanaman}$

\subsection{Panjang Tanaman Umur 40 Hari Tetelah Tanam}

Hasil sidik ragam menunjukkan bahwa perlakuan pupuk kompos (K) berpengaruh sangat nyata, sedangkan perlakuan pupuk NPK Phonska (P) dan Interaksinya $(\mathrm{KxP})$ tidak berpengaruh nyata terhadap panjang tanaman umur 40 hari setelah tanam (Tabel 1).

Hasil uji BNT 5\% terhadap panjang tanaman pada perlakuan pupuk kompos (K) menunjukkan bahwa perlakuan $\mathrm{k}_{2}$ berbeda nyata dengan perlakuan $\mathrm{k}_{1}$ dan $\mathrm{k}_{0}$. Perlakuan $\mathrm{k}_{1}$ tidak berbeda nyata dengan perlakuan $\mathrm{k}_{0}$. Tanaman terpanjang terdapat pada perlakuan $\mathrm{k}_{2}$ (dosis pupuk kompos 20 ton/ha) yaitu $142,69 \mathrm{~cm}$, sedangkan tanaman terpendek terdapat pada perlakuan $\mathrm{k}_{0}$ (tanpa pupuk kompos atau kontrol), yaitu $111,31 \mathrm{~cm}$.

\subsection{Umur Berbunga Mentimun}

Hasil sidik ragam menunjukkan bahwa perlakuan pupuk kompos (K) dan pupuk NPK Phonska (P) serta Interaksinya $(\mathrm{KxP})$ tidak berpengaruh nyata terhadap umur berbunga (Tabel 1).

\subsection{Panjang Buah Mentimun}

Hasil sidik ragam menunjukkan bahwa perlakuan pupuk kompos (K) dan pupuk NPK Phonska (P) serta
Interaksinya $(\mathrm{KxP})$ berpengaruh sangat nyata terhadap panjang buah.

Hasil uji BNT 5\% terhadap panjang buah pada perlakuan pupuk kompos (K) menunjukkan bahwa perlakuan $\mathrm{k}_{2}, \mathrm{k}_{1}$ dan $\mathrm{k}_{0}$ satu sama lainnya saling berbeda nyata. Buah terpanjang terdapat pada perlakuan $\mathrm{k}_{2}$ (dosis pupuk 20 ton/ha), yaitu 24,63 cm, sedangkan buah terpendek terdapat pada perlakuan $\mathrm{k}_{0}$ (tanpa pupuk kompos atau kontrol), yaitu $23,59 \mathrm{~cm}$.

Hasil uji BNT 5\% terhadap panjang buah pada perlakuan pupuk NPK Phonska (K) menunjukkan bahwa perlakuan $\mathrm{p}_{3}, \mathrm{p}_{2}, \mathrm{p}_{1}$ dan $\mathrm{p}_{0}$ satu sama lainnya saling berbeda nyata. Buah terpanjang terdapat pada perlakuan $\mathrm{p}_{3}$ (dosis pupuk NPK Phonska $300 \mathrm{~kg} / \mathrm{ha}$ ), yaitu 25,42 cm, sedangkan buah terpendek terdapat pada perlakuan $\mathrm{p}_{0}$ (tanpa pupuk NPK Phonska atau kontrol), yaitu $22,93 \mathrm{~cm}$.

Hasil uji BNT 5\% terhadap panjang buah pada interaksi perlakuan pupuk kompos dan pupuk NPK Phonska (KxP) menunjukkan bahwa perlakuan $\mathrm{k}_{2} \mathrm{p}_{3}$ berbeda nyata dengan perlakuan $\mathrm{k}_{1} \mathrm{p}_{3}$, $\mathrm{k}_{2} \mathrm{p}_{2}, \mathrm{k}_{1} \mathrm{p}_{2}, \mathrm{k}_{0} \mathrm{p}_{3}, \mathrm{k}_{2} \mathrm{p}_{1}, \mathrm{k}_{0} \mathrm{p}_{2}, \mathrm{k}_{1} \mathrm{p}_{1}, \mathrm{k}_{0} \mathrm{p}_{1}$, $\mathrm{k}_{1} \mathrm{p}_{0}, \mathrm{k}_{2} \mathrm{p}_{0}$ dan $\mathrm{k}_{0} \mathrm{p}_{0}$. Perlakuan $\mathrm{k}_{1} \mathrm{p}_{3}$ tidak berbeda nyata dengan perlakuan $\mathrm{k}_{2} \mathrm{p}_{2}$, tetapi berbeda nyata dengan perlakuan $\mathrm{k}_{1} \mathrm{p}_{2}, \mathrm{k}_{0} \mathrm{p}_{3}, \mathrm{k}_{2} \mathrm{p}_{1}, \mathrm{k}_{0} \mathrm{p}_{2}, \mathrm{k}_{1} \mathrm{p}_{1}, \mathrm{k}_{0} \mathrm{p}_{1}, \mathrm{k}_{1} \mathrm{p}_{0}$ $\mathrm{k}_{2} \mathrm{p}_{0}$ dan $\mathrm{k}_{0} \mathrm{p}_{0}$. Perlakuan $\mathrm{k}_{2} \mathrm{p}_{2}$ tidak berbeda nyata dengan perlakuan $\mathrm{k}_{1} \mathrm{p}_{2}$ dan $\mathrm{k}_{0} \mathrm{p}_{3}$, tetapi berbeda nyata dengan perlakuan $\mathrm{k}_{2} \mathrm{p}_{1}, \mathrm{k}_{0} \mathrm{p}_{2}, \mathrm{k}_{1} \mathrm{p}_{1}, \mathrm{k}_{0} \mathrm{p}_{1}, \mathrm{k}_{1} \mathrm{p}_{0}, \mathrm{k}_{2} \mathrm{p}_{0}$ 
dan $\mathrm{k}_{0} \mathrm{p}_{0}$. Perlakuan $\mathrm{k}_{1} \mathrm{p}_{2}$ tidak berbeda nyata dengan perlakuan $\mathrm{k}_{0} \mathrm{p}_{3}, \mathrm{k}_{2} \mathrm{p}_{1}, \mathrm{k}_{0} \mathrm{p}_{2}$ dan $\mathrm{k}_{1} \mathrm{p}_{1}$, tetapi berbeda nyata dengan perlakuan $\mathrm{k}_{0} \mathrm{p}_{1}, \mathrm{k}_{1} \mathrm{p}_{0}, \mathrm{k}_{2} \mathrm{p}_{0}$ dan $\mathrm{k}_{0} \mathrm{p}_{0}$. Perlakuan $\mathrm{k}_{0} \mathrm{p}_{3}, \mathrm{k}_{2} \mathrm{p}_{1}, \mathrm{k}_{0} \mathrm{p}_{2}$ dan $\mathrm{k}_{1} \mathrm{p}_{1}$ tidak berbeda nyata dengan perlakuan $\mathrm{k}_{0} \mathrm{p}_{1}$, tetapi berbeda nyata dengan perlakuan $\mathrm{k}_{1} \mathrm{p}_{0}, \mathrm{k}_{2} \mathrm{p}_{0}$ dan $\mathrm{k}_{0} \mathrm{p}_{0}$. Perlakuan $\mathrm{k}_{0} \mathrm{p}_{1}$ tidak berbeda nyata dengan perlakuan $\mathrm{k}_{1} \mathrm{p}_{0}$ dan $\mathrm{k}_{2} \mathrm{p}_{0}$, tetapi berbeda nyata dengan perlakuan $\mathrm{k}_{0} \mathrm{p}_{0}$. Perlakuan $\mathrm{k}_{1} \mathrm{p}_{0}, \mathrm{k}_{2} \mathrm{p}_{0}$ dan $\mathrm{k}_{0} \mathrm{p}_{0}$ saling tidak berbeda nyata. Buah terpanjang terdapat pada perlakuan $\mathrm{k}_{2} \mathrm{p}_{3}$ (dosis pupuk kompos 20 ton/ha dan dosis pupuk NPK Phonska $300 \mathrm{~kg} / \mathrm{ha}$ ), yaitu $26,75 \mathrm{~cm}$, sedangkan buah terpendek terdapat pada perlakuan $\mathrm{k}_{0} \mathrm{p}_{0}$ (perlakuan tanpa pupuk kompos dan tanpa pupuk NPK Phonska atau kontrol), yaitu 22,80 $\mathrm{cm}$.

\subsection{Diameter Buah Mentimun}

Hasil sidik ragam menunjukkan bahwa perlakuan pupuk kompos (K) dan pupuk NPK Phonska (P) berpengaruh sangat nyata, sedangkan interaksinya (KxP) tidak berpengaruh nyata terhadap diameter buah.

Hasil uji BNT 5\% terhadap diameter buah pada perlakuan pupuk kompos (K) menunjukkan bahwa perlakuan $\mathrm{k}_{2}$ tidak berbeda nyata dengan perlakuan $\mathrm{k}_{1}$, tetapi berbeda nyata dengan perlakuan $\mathrm{k}_{0}$. Perlakuan $\mathrm{k}_{1}$ berbeda nyata dengan perlakuan $\mathrm{k}_{0}$. Diameter buah terbesar terdapat pada perlakuan $\mathrm{k}_{2}$ (dosis pupuk kompos 20 ton/ha), yaitu $5,73 \mathrm{~cm}$, sedangkan diameter buah terkecil terdapat pada perlakuan $\mathrm{k}_{0}$ (tanpa pupuk kompos atau kontrol), yaitu $5,49 \mathrm{~cm}$.

Hasil uji BNT 5\% terhadap panjang buah pada perlakuan pupuk NPK Phonska (K) menunjukkan bahwa perlakuan $\mathrm{p}_{3}$ berbeda nyata dengan perlakuan $\mathrm{p}_{2}, \mathrm{p}_{1}$ dan $\mathrm{p}_{0}$. Perlakuan $\mathrm{p}_{2}$ berbeda nyata dengan perlakuan $\mathrm{p}_{1}$ dan $\mathrm{p}_{0}$. Perlakuan $\mathrm{p}_{1}$ tidak berbeda nyata dengan perlakuan $\mathrm{p}_{0}$. Diameter buah terbesar terdapat pada perlakuan $\mathrm{p}_{3}$ (dosis pupuk NPK Phonska 300/ha), yaitu 5,97 $\mathrm{cm}$, sedangkan diameter buah terkecil terdapat pada perlakuan $\mathrm{p}_{0}$ (tanpa pupuk NPK Phonska atau kontrol), yaitu 5,33 $\mathrm{cm}$.

\subsection{Jumlah Buah Per Tanaman Mentimun}

Hasil sidik ragam menunjukkan bahwa perlakuan pupuk kompos (K) berpengaruh nyata, perlakuan pupuk NPK Phonska (P) berpengaruh sangat nyata, sedangkan interaksinya (KxP) tidak berpengaruh nyata terhadap jumlah buah per tanaman.

Hasil uji BNT 5\% terhadap jumlah buah per tanaman pada perlakuan pupuk kompos (K) menunjukkan bahwa perlakuan $\mathrm{k}_{2}$ tidak berbeda nyata dengan perlakuan $\mathrm{k}_{1}$, tetapi berbeda nyata dengan perlakuan $\mathrm{k}_{0}$. Perlakuan $\mathrm{k}_{1}$ tidak berbeda nyata dengan perlakuan $\mathrm{k}_{0}$. Jumlah buah per tanaman paling banyak terdapat pada perlakuan $\mathrm{k}_{2}$ (dosis pupuk kompos 20 ton/ha), yaitu 9,75 buah, sedangkan jumlah buah per tanaman paling sedikit terdapat pada perlakuan $\mathrm{k}_{0}$ (tanpa pupuk kompos atau kontrol), yaitu 9,25 cm.

Hasil uji BNT 5\% terhadap panjang buah pada perlakuan pupuk NPK Phonska (K) menunjukkan bahwa perlakuan $\mathrm{p}_{3}, \mathrm{p}_{2}, \mathrm{p}_{1}$ dan $\mathrm{p}_{0}$ satu sama lainnya saling berbeda nyata. Jumlah buah per tanaman paling banyak terdapat pada perlakuan $\mathrm{p}_{3}$ (dosis NPK Phonska $300 /$ ha), yaitu 10,75 buah, sedangkan jumlah buah per tanaman paling sedikit terdapat pada perlakuan $\mathrm{p}_{0}$ (tanpa pupuk NPK Phonska atau kontrol), yaitu 8,42 $\mathrm{cm}$.

\subsection{Berat Buah Per Tanaman}

Hasil sidik ragam menunjukkan bahwa perlakuan pupuk kompos (K) dan pupuk NPK Phonska (P) serta Interaksinya $(\mathrm{KxP})$ berpengaruh sangat nyata terhadap berat buah per tanaman 
Hasil uji BNT 5\% terhadap berat buah per tanaman pada perlakuan pupuk kompos (K) menunjukkan bahwa perlakuan $\mathrm{k}_{2}, \mathrm{k}_{1}$ dan $\mathrm{k}_{0}$ satu sama lainnya saling berbeda nyata. Berat buah terberat per tanaman terdapat pada perlakuan $\mathrm{k}_{2}$ (dosis pupuk 20 ton/ha), yaitu 3,45 $\mathrm{kg} /$ tanaman, sedangkan berat buah teringan per tanaman terdapat pada perlakuan $\mathrm{k}_{0}$ (tanpa pupuk kompos atau kontrol), yaitu 2,61 kg/tanaman.

Hasil uji BNT 5\% terhadap berat buah per tanaman pada perlakuan pupuk NPK Phonska (K) menunjukkan bahwa perlakuan $\mathrm{p}_{3}, \mathrm{p}_{2}, \mathrm{p}_{1}$ dan $\mathrm{p}_{0}$ satu sama lainnya saling berbeda nyata. Produksi buah terberat per tanaman terdapat pada perlakuan $\mathrm{p}_{3}$ (dosis pupuk NPK Phonska $300 \mathrm{~kg} / \mathrm{ha}$ ), 3,16 kg/tanaman, sedangkan produksi buah teringan terdapat pada perlakuan $\mathrm{p}_{0}$ (tanpa pupuk NPK Phonska atau kontrol), yaitu $2,79 \mathrm{~kg} /$ tanaman.

Hasil uji BNT 5\% terhadap berat buah per tanaman pada interaksi perlakuan pupuk kompos dan perlakuan pupuk NPK Phonska (KxP) menunjukkan bahwa perlakuan $\mathrm{k}_{2} \mathrm{p}_{3}$ berbeda nyata dengan perlakuan $\mathrm{k}_{2} \mathrm{p}_{2}, \mathrm{k}_{2} \mathrm{p}_{1}, \mathrm{k}_{2} \mathrm{p}_{0}, \mathrm{k}_{1} \mathrm{p}_{3}$, $\mathrm{k}_{1} \mathrm{p}_{2}, \mathrm{k}_{1} \mathrm{p}_{1}, \mathrm{k}_{1} \mathrm{p}_{0}, \mathrm{k}_{0} \mathrm{p}_{3}, \mathrm{k}_{0} \mathrm{p}_{2}, \mathrm{k}_{0} \mathrm{p}_{1}$ dan $\mathrm{k}_{0} \mathrm{p}_{0}$. Perlakuan $\mathrm{k}_{2} \mathrm{p}_{2}$ berbeda nyata dengan perlakuan $\mathrm{k}_{2} \mathrm{p}_{1}, \mathrm{k}_{2} \mathrm{p}_{0}, \mathrm{k}_{1} \mathrm{p}_{3}, \mathrm{k}_{1} \mathrm{p}_{2}, \mathrm{k}_{1} \mathrm{p}_{1}$, $\mathrm{k}_{1} \mathrm{p}_{0}, \mathrm{k}_{0} \mathrm{p}_{3}, \mathrm{k}_{0} \mathrm{p}_{2}, \mathrm{k}_{0} \mathrm{p}_{1}$ dan $\mathrm{k}_{0} \mathrm{p}_{0}$. Perlakuan $\mathrm{k}_{2} \mathrm{p}_{1}$ berbeda nyata dengan perlakuan $\mathrm{k}_{2} \mathrm{p}_{0}, \mathrm{k}_{1} \mathrm{p}_{3}, \mathrm{k}_{1} \mathrm{p}_{2}, \mathrm{k}_{1} \mathrm{p}_{1}, \mathrm{k}_{1} \mathrm{p}_{0}, \mathrm{k}_{0} \mathrm{p}_{3}, \mathrm{k}_{0} \mathrm{p}_{2}$, $\mathrm{k}_{0} \mathrm{p}_{1}$ dan $\mathrm{k}_{0} \mathrm{p}_{0}$. Perlakuan $\mathrm{k}_{1} \mathrm{p}_{3}$ tidak berbeda nyata dengan perlakuan $\mathrm{k}_{1} \mathrm{p}_{2}$, tetapi berbeda nyata dengan perlakuan $\mathrm{k}_{1} \mathrm{p}_{2}, \mathrm{k}_{1} \mathrm{p}_{1}, \mathrm{k}_{1} \mathrm{p}_{0}, \mathrm{k}_{0} \mathrm{p}_{3}, \mathrm{k}_{0} \mathrm{p}_{2}, \mathrm{k}_{0} \mathrm{p}_{1}$ dan $\mathrm{k}_{0} \mathrm{p}_{0}$. Perlakuan $\mathrm{k}_{1} \mathrm{p}_{2}$ tidak berbeda nyata dengan perlakuan $\mathrm{k}_{1} \mathrm{p}_{1}$, tetapi berbeda nyata dengan perlakuan $\mathrm{k}_{1} \mathrm{p}_{0}, \mathrm{k}_{0} \mathrm{p}_{3}, \mathrm{k}_{0} \mathrm{p}_{2}$, $\mathrm{k}_{0} \mathrm{p}_{1}$ dan $\mathrm{k}_{0} \mathrm{p}_{0}$. Perlakuan $\mathrm{k}_{1} \mathrm{p}_{1}$ tidak berbeda nyata dengan perlakuan $\mathrm{k}_{1} \mathrm{p}_{0}$ dan $\mathrm{k}_{0} \mathrm{p}_{3}$, tetapi berbeda nyata dengan perlakuan $\mathrm{k}_{0} \mathrm{p}_{2}, \mathrm{k}_{0} \mathrm{p}_{1}$ dan $\mathrm{k}_{0} \mathrm{p}_{0}$. Perlakuan $\mathrm{k}_{1} \mathrm{p}_{0}$ dan $\mathrm{k}_{0} \mathrm{p}_{3}$ tidak berbeda nyata dengan perlakuan $\mathrm{k}_{0} \mathrm{p}_{2}$ dan $\mathrm{k}_{0} \mathrm{p}_{1}$, tetapi berbeda nyata dengan perlakuan $\mathrm{k}_{0} \mathrm{p}_{0}$. Perlakuan $\mathrm{k}_{0} \mathrm{p}_{2}$ dan $\mathrm{k}_{0} \mathrm{p}_{1}$ tidak berbeda nyata dengan perlakuan $\mathrm{k}_{0} \mathrm{p}_{0}$.

Pengaruh Pupuk Kompos Terhadap Pertumbuhan dan Hasil Tanaman Mentimun (Cucumis sativus L.) Varietas Harmony. Hasil sidik ragam menunjukkan bahwa perlakuan pupuk kompos tidak berpengaruh nyata terhadap panjang tanaman umur 20 hari setelah tanam dan umur berbunga. Berpengaruh nyata terhadap jumlah buah per tanaman. Berpengaruh sangat nyata terhadap panjang tanaman umur 40 hari setelah tanam, panjang buah, diameter buah dan produksi buah per tanaman dan berat buah per tanaman.

Perlakuan pupuk kompos tidak berpengaruh nyata terhadap panjang tanaman umur 20 hari setelah tanam, keadaan ini disebabkan karena tanaman masih kecil, akar tanaman belum berkembang dengan sempurna, sehingga akar tanaman belum mampu menyerap unsur hara yang terkandung dalam pupuk kompos.

Pemberian pupuk kompos berpengaruh sangat nyata terhadap panjang tanaman umur 40 hari setelah tanam, hal ini diduga bahwa pupuk kompos yang diberikan kedalam tanah telah mampu diserap oleh akar tanaman mentimun, karena dengan bertambahnya umur maka akar tanaman telah berkembang dengan baik, sehingga mampu menyerap unsur hara yang terkandung didalam pupuk kompos, seperti unsur $\mathrm{N}, \mathrm{P}$ dan $\mathrm{K}$ serta unsur mikro, untuk meningkatkan pertumbuhan tanaman mentimun, seperti panjang tanaman.

Pemberian pupuk kompos tidak berpengaruh nyata terhadap waktu munculnya bunga, hal ini diduga bahwa pupuk kompos yang diberikan merupakan salah satu faktor yang menentukan pertumbuhan baik vegetatif maupun generatif, sedangkan faktor dalam (sifat genetik) tanaman juga 
merupakan faktor penting dalam pertumbuah tanaman. Seperti dikemukakan oleh Gardner dkk., (2008), bahwa memasuki periode pertumbuhan generatif, tanaman memerlukan ketersediaan unsur hara seperti fosfor dalam pembentukan fosfolipid dan nukleoprotein yang disimpan di dalam biji. Selanjutnya Sutedjo (2008) menambahkan bahwa unsur fosfor $(\mathrm{P})$ berfungsi mempercepat masa pembungaan, pemasakan buah dan biji. pemberian pupuk tunggal anorganik mau pun pemberian pupuk organonitrofos mampu meningkatkan serapan hara $\mathrm{N}, \mathrm{P}$ dan $\mathrm{K}$ pada tanaman dan buah mentimun (Wijaya dkk., 2015).

Berdasarkan hasil sidik ragam, pemberian pupuk kompos berpengaruh terhadap panjang buah, diameter buah, jumlah buah dan berat buah per tanaman. Berdasarkan data yang terdapat pada Tabel 1, pemberian pupuk kompos dengan dosis 20 ton/ha (setara 800 ton/ha) memberikan hasil buah yang lebih baik, yatu panjang buahnya 24,63 $\mathrm{cm}$, diameter buah $5,73 \mathrm{~cm}$, jumlah buah 9,75 buah dan berat buah 3,45 $\mathrm{kg} /$ tanaman, dibandingkan perlakuan dengan dosis 10 ton/ha (setara 400 g/tanaman dan perlakuan kontrol (tanpa pupuk kompos), yaitu menghasilkan panjang buah $23,59 \mathrm{~cm}$, diameter buah $5,49 \mathrm{~cm}$, jumlah buah 9,25 buah dan berat buah 2,61 kg/tanaman. Bila dibandingkan dengan data pada deskripsi tanaman mentimun varietas Harmony, jumlah buah per tanaman 8 buah dengan berat buah 2,4 kg/tanaman, hasil penelitian seperti jumlah buah dan berat buah per tanaman relatif lebih tinggi, dibandingkan denga deskripsi varietas Harmony. Keadaan ini disebabkan dengan pemberian pupuk kompos pada budidaya tanaman mentimun terbukti sangat membantu dalam memperbaiki kesuburan tanah dan juga sifat fisik dan biologi tanah. Walaupun unsur hara yang terkandung dalam pupuk kompos sangat sedikit, namun jumlah unsur haranya lebih lengkap, karena mengandung unsur hara makro dan mikro. Keistewaan lainnya yang dimiliki pupuk kompos atau pupuk organik adalah kemampuannya untuk memperbaiki sifat fisik dan sifat biologi tanah, yang tidak dimiliki oleh jenis pupuk anorganik. Seperti dikemukakan oleh Sutanto (2012), bahwa pupuk kompos membantu memperbaiki struktur tanah dengan meningkatkan kandungan bahan organik tanah dan akan meningkatkan kemampuan tanah untuk mempertahankan kandungan air tanah. Menurut Hardjowigeno (2010), menambahkan bahwa pemberian pupuk organik selain menambah unsur hara, dapat pula memperbaiki struktur tanah, meningkatkan kasitas tukar kation, menambah kemampuan tanah menahan air dan meningkatkan kegiatan biologi tanah. Bahkan pada beberapa tanah masam, dapat meningkatkan $\mathrm{pH}$ tanah. Kompos dibuat dari bahan organik yang berasal dari bermacam-macam sumber. Dengan demikian, kompos merupakan sumber bahan organik dan nutrisi tanaman (Sutanto, 2010).

Oleh sebab itu walaupun hasil analisis tanah penelitian $\mathrm{pH}$ nya 4,00 , yaitu tergolong sangat masam (Hasil Analisa Tanah), namun memberikan hasil yang lebih baik dibandingkan dengan hasil yang tertera pada deskripsi varietas Harmony

Pengaruh Pupuk NPK Phonska Terhadap Pertumbuhan dan Hasil Tanaman Mentimun (Cucumis sativus L.) Varietas Harmony. Hasil sidik ragam, menunjukkan bahwa perlakuan pupuk NPK Phonska tidak berpengaruh nyata terhadap panjang tanaman umur 20 hari dan umur 40 hari setelah tanam dan umur berbunga. Berpengaruh sangat nyata terhadap panjang buah, diameter buah, jumlah buah per tanaman dan berat buah per tanaman. 
Perlakuan pupuk NPK Phonska tidak berpengaruh nyata terhadap panjang tanaman umur 20 hari dan 40 hari setelah tanam. Keadaan ini diduga disebabkan kondisi media tanah penelitian berdasarkan hasil analisis tanah di laboratorium tergolong sangat masam, yaitu $\mathrm{pH} 4,00$, keadaan ini menyebabkan beberapa unsur hara makro sukar larut, seperti dikemukakan oleh Hardjowigeno (2010), bahwa dalam kondisi tanah masam seperti unsur P tidak dapat diserap tanaman, karena diikat (difiksasi) oleh unsur $\mathrm{Al}$, yang banyak ditemukan dan mudah larut. Disamping itu juga pupuk NPK Phonska termasuk pupuk yang lambat terurai, sehingga memerlukan waktu untuk dapat diserap oleh akar tanaman, walaupun curah hujan selama penelitian cukup mendukung untuk melarutkan unsur hara tersebut, yaitu rata-rata curah hujan per bulan kurang lebih $200 \mathrm{~mm}$.

Berdasarkan hasil sidik ragam perlakuan pupuk NPK Phonska tidak berpengaruh terhadap umur berbunga. Keadaan ini disebabkan bahwa masa berbunga tidak hanya ditentukan oleh faktor tanah (unsur hara) tetapi juga ditentukan oleh faktor genetik dan faktor luar lainnya, seperti faktor iklim (fotoperiode atau lamanya waktu penyinaran), seperti dikemukakan oleh Dwijoseputro (1978) dan Samadi (2006), bahwa masa pembungaan selain dipengaruhi oleh penyinaran dan suhu, juga bisa disebabkan kelembaban udara dan tanah, serta keadaan nutrisi (unsur hara) didalam tanah.

Berdasarkan hasil sidik ragam perlakuan pupuk NPK Phonska berpengaruh sangat nyata terhadap panjang buah, diameter buah, jumlah buah dan berat buah per tanaman. Keadaan ini diduga disebabkan dengan semakin bertambahnya umur tanaman menjadi dewasa (fase pertumbuhan generatif), maka pupuk NPK Phonska yang diberikan telah banyak terurai ke dalam tanah, sehingga unsur-unsur hara tersebut dapat diserap oleh tanaman. Pemberian pupuk NPK Phonska dengan dosis $300 \mathrm{~kg} / \mathrm{ha}$ (setara $12 \mathrm{~g} /$ tanaman) cenderung menghasilkan panjang buah, diameter buah, jumlah buah dan berat buah per tanaman yang lebih baik, dibandingkan dengan perlakuan lainnya, yaitu perlakuan dengan dosis pupuk 200 $\mathrm{kg} / \mathrm{ha}$ (setara $8 \mathrm{~g} /$ tanam), dan dosis pupuk $100 \mathrm{~kg} / \mathrm{ha} \quad$ (setara $4 \mathrm{~g} /$ tanaman). Berdasarkan data penelitian (Lampiran Tabel 8), bila dosis pupuk NPK yang diberikan meningkat, maka hasilnya cendrung meningkat pula. Pada perlakuan pupuk NPK Phonska dengan dosis 300 $\mathrm{kg} / \mathrm{ha}$ atau setara 12 g/tanaman (perlakuan $\mathrm{p}_{3}$ ), menghasilkan panjang buah $25,42 \mathrm{~cm}$, diameter buah $5,97 \mathrm{~cm}$, jumlah buah 10,75 buah/tanaman dan berat buah $3,16 \mathrm{~kg}$ per tanaman, sedangkan pada perlakuan $\mathrm{p}_{0}$ (tanpa pupuk NPK Phonska atau kontrol), menghasilkan panjang buah 22,93 cm, diameter buah $5,33 \mathrm{~cm}$, jumlah buah 8,42 buah per tanaman dan berat buah 2,79 $\mathrm{kg} / \mathrm{tanaman}$. Hasil yang diperoleh pada perlakuan $\mathrm{p}_{3}$ lebih baik dibandingkan dengan hasil pada perlakuan $\mathrm{p}_{0}$ (perlakuan kontrol). Keadaan ini menunjukkan bahwa semakin meningkat dosis pupuk NPK Phonska yang diberikan cendrung meningkatkan hasil yang lebih baik, hal ini disebabkan bahwa semakin banyak pupuk NPK Phonska yang diberikan kedalam tanah (media tanam dalam polibag), maka semakin banyak unsur hara yang dapat diserap oleh tanaman untuk menghasilkan buah mentimun yang lebih banyak dan lebih berat. Hal ini terjadi karena adanya peranan unsur hara $\mathrm{N}, \mathrm{P}$ dan $\mathrm{K}$ yang terkandung dalam pupuk NPK Phonska.

Pupuk nitrogen berperan penting dalam pertumbuhan vegetatif dan pembentukan protein, seperti dikatakan oleh Lingga dan Marsono (2009), bahwa 
unsur nitrogen berperan penting dalam pembentukan hijau daun dan sangat berguna dalam proses fotosintesis, membentuk protein, lemak dan persenyawaan organik lainnya. Unsur fosfor juga berperan dalam pembentukan buah dan biji, seperti dikemukakan oleh Sutedjo (2008), bahwa unsur fosfor dapat mempercepat pemasakan buah dan biji. Disamping itu juga yang tidak kalah pentingnya adalah peranan unsur kalium yang berperan dalam pembentukan karbohidrat. Unsur kalium berperan sangat besar dalam pembentukan karbohidrat dan protein.

Fungsi beberapa unsur makro seperti Nitrogen, Phosfor dan Kalium bagi pertumbuhan generatif tanaman yaitu menyebabkan proses fotosintesis berjalan lancar, dan terjadi pembentukan karbohidrat dan protein, selanjutnya ditransper ke buah tanaman, sehingga buahnya semakin panjang, diameter bertambah, jumlah buah per tanaman bertambah dan akhir meningkatkan berat buah per tanaman. Perlakuan pemberian kompos berbeda nyata pada pengamatan panjang tanaman $(\mathrm{cm})$, berat buah/sampel (gr) dan tidak berbeda nyata pada pengamatan jumlah buah/sampel (buah), jumlah buah/plot (buah) dan berat buah/plot $(\mathrm{kg})$. Perlakuan terbaik adalah $\mathrm{K} 3$ yaitu 8 kg/bedengan (Harahap, 2019). perlakuan pupuk kompos berpengaruh nyata terhadap berat satu buah dan berat buah per tanaman; berpengaruh sangat nyata terhadap panjang tanaman pada umur 15 dan 30 hari setelah tanam, dan diameter buah, tetapi berpengaruh tidak nyata terhadap jumlah buah per tanaman. Buah yang paling berat dihasilkan pada perlakuan 48 g polibag $^{-1}(\mathrm{k} 1)$ yaitu 3,77 kg tanaman ${ }^{-1}$ (Lidya dan Rahmi, 2019).

Pengaruh Interaksi Perlakuan Pupuk Kompos dan Pupuk NPK Phonska Terhadap Pertumbuhan dan Hasil Tanaman Mentimun (Cucumis sativus L.) Varietas Harmony. Hasil sidik ragam, menunjukkan bahwa interaksi perlakuan antara pupuk kompos dan pupuk NPK Phonska tidak berpengaruh nyata terhadap panjang tanaman umur 20 hari dan umur 40 hari setelah tanam, umur berbunga, diameter buah dan jumlah buah per tanaman. Berpengaruh sangat nyata terhadap produksi buah/tanaman.

Secara umum interaksi perlakuan pupuk kompos dan pupuk NPK Phonska tidak berpengaruh nyata terhadap parameter penelitian yang diamati. Keadaan ini diduga karena peningkatan pertumbuhan pada fase pegetatif dan fase generatif berjalan lamban, akibat kondisi tanah dengan tingkat keasamannya sangat rendah ( $\mathrm{pH} 4,00)$, kejenuhan basa rendah $(20,06)$, KTK tinggi (49), sehingga walaupun diberikan pupuk kompos dengan dosis 20 ton/ha dan dosis pupuk NPK Phonska $300 \mathrm{~kg} / \mathrm{ha}$, unsur hara yang ada di dalam tanah sedikit sekali yang dapat dimanfaatkan oleh tanaman, karena banyak unsur hara yang difiksasi oleh unsur $\mathrm{Al}$ dan Fe. Beberapa manfaat pupuk organik adalah dapat menyediakan unsur hara makro dan mikro, mengandung asam humat (humus) yang mampu meningkatkan kapasitas tukar kation tanah, meningkatkan aktivitas bahan mikroorganisme tanah, pada tanah masam penambahan bahan organik dapat membantu meningkatkan $\mathrm{pH}$ tanah, dan penggunaan pupuk organik tidak menyebabkan polusi tanah dan polusi air (Novizan, 2007). Unsur kalium penting dalam metabolisme karbohidrat dan translokasi pati, metabolise nitrogen, aktivitas enzim, pergerakan stomata, penyerapan air dan perkembangan jaringan meristem (Winarso, 2006).

Namun demikian dengan bertambahnya umur tanaman, atau semakin dewasanya tanaman, maka pupuk kompos yang diberikan ke dalam tanah dapat memperbaiki kondisi tanahnya menjadi sedikit lebih baik, hal ini terbukti dengan dihasilkannya jumlah 
buah per tanaman dan berat buah per tanaman yang lebih tinggi dibandingkan dengan hasil yang terdapat pada deskripsi varietas Harmony.

Berdasarkan uji sidik ragam, interaksi perlakuan terhadap panjang buah, diameter buah dan jumlah buah per tanaman tidak berpengaruh nyata, tetapi berdasarkan data rata-ratanya ada kecendrungan hasilnya meningkat dengan meningkatnya dosis pupuk yang diberikan, yang pada akhir kenyataan ini terlihat pada komponen berat buah per tanaman yang merespon peningkatan dosis pupuk yang diberikan. Hal ini diduga karena dengan semakin lamanya pupuk kompos yang diberikan kedalam tanah akan memperbaiki kesuburan tanah, sifat fisik maupun sifat biologi tanah, hal ini sesuai dengan pendapat Hardjowigeno (2010), bahwa pemberian pupuk organik pada beberapa tanah masam dapat menaikkan $\mathrm{pH}$ tanah dan kapasitas tukar kation (KTK). Keadaan ini akan memberikan hasil yang lebih baik, karena unsur hara yang terfiksasi oleh larutan $\mathrm{Al}$ dan $\mathrm{Fe}$ dapat terlepas dan larut dalam tanah, sehingga dapat diserap oleh akar tanaman untuk menghasil buah mentimun yang lebih baik.

Berat buah tertinggi terdapat pada perlakuan $\mathrm{k}_{2} \mathrm{p}_{3}$ (dosis pupuk kompos 20 ton/ha dan dosis pupuk NPK Phonska $300 \mathrm{~kg} / \mathrm{ha}$ ), yaitu $3,94 \mathrm{~kg} / \mathrm{tanaman}$, sedangkan berat buah terendah terdapat pada perlakuan $\mathrm{k}_{0} \mathrm{p}_{0}$ (tanpa pupuk kompos dan pupuk NPK Phonska atau kontrol), yaitu 2,54 kg/tanaman.

\section{KESIMPULAN}

Dari hasil penelitian dapat disimpulkan sebagai berikut : Perlakuan pupuk kompos (P) tidak berpengaruh nyata terhadap panjang tanaman umur 20 hari setelah tanam dan umur berbunga. Berpengaruh nyata terhadap jumlah buah per tanaman. Berpengaruh sangat nyata terhadap panjang tanaman umur 40 hari setelah tanam, panjang buah, diameter buah, produksi buah per tanaman. Berat buah tertinggi terdapat pada perlakuan $\mathrm{k}_{2}$ (dosis pupuk kandang kompos 20 ton/ha), yaitu $3,45 \mathrm{~kg} /$ tanaman, sedangkan berat buah terendah terdapat pada perlakuan $\mathrm{k}_{0}$ (tanpa pupuk kompos atau kontrol), yaitu $2,61 \mathrm{~kg} /$ tanaman.

Perlakuan pupuk NPK Phonska (K) tidak berpengaruh nyata terhadap panjang tanaman umur 20 hari dan umur 40 hari setelah tanam dan umur berbunga. Berpengaruh sangat nyata terhadap panjang buah, diameter buah, jumlah buah per tanaman dan produksi buah per tanaman. Berat buah tertinggi terdapat pada perlakuan $\mathrm{p}_{3}$ (dosis pupuk 300 $\mathrm{kg} / \mathrm{ha}$ ), yaitu $3,16 \mathrm{~kg} /$ tanaman, sedangkan berat buah terendah terdapat pada perlakuan $\mathrm{p}_{0}$ (tanpa pupuk NPK Phonska atau kontrol), yaitu $2,79 \mathrm{~kg} / \mathrm{tanaman}$.

Interaksi perlakuan antara pupuk kompos dan pupuk NPK Phonska ( $\mathrm{P}$ x $\mathrm{K})$ tidak berpengaruh nyata terhadap panjang tanaman umur 20 hari dan umur 40 hari setelah tanam, umur berbunga, diameter buah dan jumlah buah per tanaman. Berpengaruh sangat nyata terhadap produksi buah/tanaman. Berat buah tertinggi terdapat pada perlakuan $\mathrm{k}_{2} \mathrm{p}_{3}$ (dosis pupuk kompos 20 ton/ha dan dosis pupuk NPK Phonska $300 \mathrm{~kg} / \mathrm{ha}$ ), yaitu $3,94 \mathrm{~kg} /$ tanaman, sedangkan berat buah terendah terdapat pada perlakuan $\mathrm{k}_{0} \mathrm{p}_{0}$ (tanpa pupuk kompos dan pupuk NPK Phonska atau kontrol), yaitu 2,54 $\mathrm{kg} / \mathrm{tanaman}$.

\section{DAFTAR PUSTAKA}

Dwijoseputro, D. (1978). Pengantar Fisiologi Tumbuhan. Jakarta: Gramedia.

Gardner, F.P, Pearce R.B dan Mitchell R.L. (2008). Fisiologi Tanaman 
Budidaya. Jakarta: Universitas Indonesia Press.

Harahap, S. (2019). Pengaruh Pemberian Kompos dan Pupuk Organik Cair pada Pertumbuhan dan Produksi Tanaman Mentimun (Cucumis Sativus L.). Graha Tani, 5(2), 739745.

Hardjowigeno, S. (2010). Ilmu Tanah. Jakarta: Akademika Pressindo.

Lidya, E., \& Rahmi, A. (2019). Pengaruh Pupuk Kompos Dan Pupuk Organik Cair Nasa Terhadap Pertumbuhan Dan Hasil Tanaman Mentimun (Cucumis sativus L.) Varietas Misano F1. AGRIFOR, 18(2), 231240.

Lingga, P dan Marsono. (2009). Petunjuk Penggunaan Pupuk. Jakarta: Penebar Swadaya.

Novizan, (2007). Petunjuk Pemupukan Yang Efektif. Jakarta: Agromedia Pustaka.

Rukmana, R. (2010). Budidaya Mentimun. Jakarta: Kanisius.

Samadi, B. (2006). Teknik Budidaya Mentimun Hibrida. Yogyakarta: Kanisius.
Sumpena, U. (2008). Budidaya Mentimun Intensif Dengan Mulsa Secara Tumpang Gilir. Jakarta: Penebar Swadaya.

Sutanto, R. (2010). Dasar-Dasar Ilmu Tanah, Konsep dan Kenyataan. Yogyakarta: Kanisius.

Sutanto, R. (2012). Pertanian Organik Menuju Pertanian Alternatif dan Berkelanjutan. Yogyakarta: Penerbit Kanisius.

Sutedjo, M.M. (2008). Pupuk dan Cara Pemupukan. Jakarta: Rineka Cipta.

Wijaya, A. A., Lumbanraja, J., \& Ginting, Y. C. (2015). Uji Efektivitas Pupuk Organonitrofos Dan Kombinasinya Dengan Pupuk Anorganik Terhadap Pertumbuhan, Serapan Hara Dan Produksi Tanaman Mentimun (Cucumis Sativus L.) Pada Musim Tanam Kedua Di Tanah Ultisol Gedung Meneng. Jurnal Agrotek Tropika, 3(3), 409-421.

Winarso, S. (2006). Kesuburan Tanah, Dasar Kesehatan dan Kualitas Tanah. Yogyakarta: Gava Media.

Yitnosumarto, S. (1993). Percobaan, Perancangan, Analisis dan Interpretasinya. Jakarta: Gramedia. 